\section{Volcano prediction problems}

\section{Tokyo}

LAST week's eruption of Mount Unzen, which killed 37 people, has highlighted the problems of volcano prediction and disaster prevention in Japan. In the days leading up to the Unzen tragedy, Japan's volcano experts and disaster prevention officials recognized the danger of the mountain erupting and even evacuated a nearby residential area, but they did not fully anticipate the particular threat that claimed the 37 lives. The episode is the latest in a string of recent volcanic eruptions in Japan that have defied the public predictions of experts.

Before the eruption, the warnings of various government disaster prevention organizations focused public attention on the possibility that mudflows from the volcano might hit the town of Shimabara at the foot of Unzen. But it was instead a pyroclastic flow - a very fast-moving mixture of gas and rocks - that engulfed unprepared researchers, journalists, firemen and policemen.

Daisuke Shimozuru, chairman of a government committee for predicting volcanic eruptions, defended his committee's record last week by saying that it had warned that pyroclastic flows might occur. The committee's public pronouncements, however, did not explain what a pyroclastic flow is, how deadly it is, or how fast it can strike.

Similarly, the Meteorological Agency, which is also responsible for issuing warnings, spoke repeatedly about the possibility of mudflows right up to the day of the disaster, but mentioned pyroclastic flows only in passing. And a few weeks before the erup-

\section{IMAGE UNAVAILABLE FOR COPYRIGHT REASONS}

tion, local government officials were quoted as saying that the lava flows from Unzen were slow moving and viscous - and therefore not so dangerous - and that their chief concern was mudflows.

This is not the first time a Japanese volcano has not behaved as predicted by government officials. In 1986, when the volcanic island of Oshima near Tokyo began rumbling, the volcanic prediction committee announced that an eruption was not imminent. A few days later, the eruption started. At that point, the committee predicted that lava flows would be confined to the volcano's caldera, and about 2,000 tourists flocked to the island to watch the spectacular eruptions. When the eruptions calmed down, the Meteorological Agency announced that activity seemed to be over.

A few hours later, a line of vents opened up across the caldera wall, lava poured down towards the main village, and 10,000 islanders (as well as the 2,000 tourists) had to be evacuated from the island overnight.

In 1989, when a series of earthquakes hit the resort city of Ito on the coast of Sagami Bay about $100 \mathrm{~km}$ from Tokyo, the government's earthquake prediction committee initially attributed the earthquakes to plate tectonic movement in the area. Local fishermen pointed out that brown water was bubbling to the surface of the sea and dead fish were being washed ashore. But this information was ignored. After earthquake activity calmed down briefly, the Meteorological Agency announced that the earthquakes seemed to be subsiding and warnings for residents were lifted.

Hours later, strange booming sounds were heard emanating from the ground in Ito, and only then did the experts begin to talk seriously about the possibility that the earthquakes might be caused by magma rising to the surface. Before any predictions could be made, a submarine volcano broke through the sea's surface $1 \mathrm{~km}$ offshore.

The picture is further confused by the multitude of government-related organizations and committees - both national and local - involved in disaster prevention and prediction, a situation that tends to diffuse responsibility for public pronouncements. Perhaps the most surprising thing for Western observers is that, despite all that has happened in the past few years, the various disaster related organizations continue to make predictions and warnings, and the Japanese public continues to listen. David Swinbanks Among those killed by last week's eruption of Mount Unzen were a French husband and-wife team of volcanologists and a US geologist.

Maurice and Katia Krafft, famous and ash at Mt Unzen.

\section{Eruptions no secret}

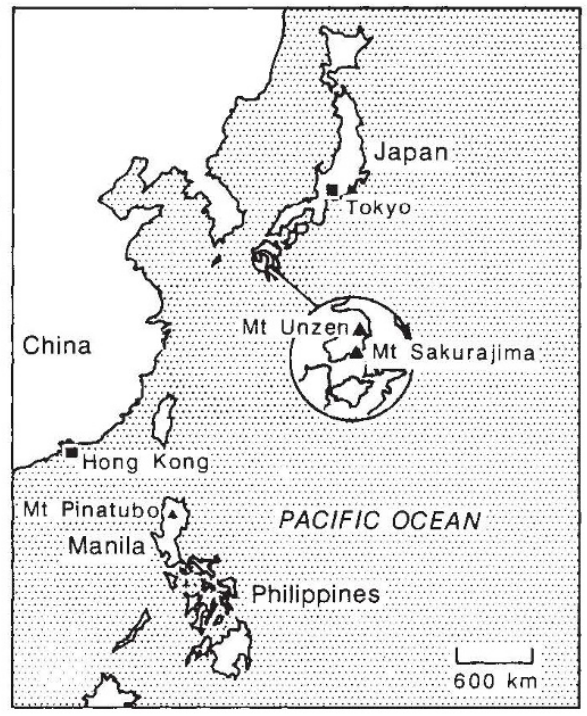

A series of volcanic eruptions in Japan and the Philippines in the past ten days may not have been the largest or most damaging volcanic events in history, but they were among the most heavily monitored. Over the past several years, researchers have installed instruments to watch for local tremors, gas emissions, sweiling and thermal changes around the volcanoes. In the case of the Mount Unzen, which exploded earlier this month, measurements predicted an eruption two months before the event, which allowed officials to evacuate the area and minimize injuries.

The eruption last week of Mount Pinatubo in the Philippines and warning signs of a possible eruption at Mount Sakurajima in Japan were also predicted several weeks ago by volcanologists monitoring the volcanoes. of the 550 active volcanoes worldwide, more than a hundred are currently monitored with some instrumentation, and several dozen have a full complement of earthquake, gas and size-change instruments to warn of impending eruptions, says US Geological Survey researcherTom Cassadeval

C.A

taries of erupting volcanoes, flew to Japan just two weeks ago to film Mount Unzen because the erupting volcano provides a rare opportunity to observe pyroclastic flows in action.

They were accompanied by Harry Glicken, a US visiting postdoctoral fellow at Tokyo Metropolitan University, who formerly worked for the US Geological Survey and was an expert on Japan's volcanoes, in particular Mount Unzen.

All three were well aware of the dangers of approaching the volcano. Shortly before leaving for Unzen, Glicken said in Tokyo that the eruption was in many ways similar to that of Mont Pelée in Martinique in 1902 , which destroyed St Pierre, the capital of the island and killed all 30,000 residents except for one prisoner in an underground cell. The three scientists, whose bodies were found last Thursday, had apparently ventured closer than anyone else to the foot of the erupting volcano. 